\title{
THE CONSTRUCTION OF NATIONAL IDENTITY IN SHAKESPEARE'S KING LEAR AND ITS FILMIC ADAPTATION BY PETER BROOK
}

Antonio João Teixeira

Universidade Estadual de Ponta Grossa

\section{Abstract}

The national consciousness that had begun in the reign of Queen Elizabeth I-due to the enmity that England had with France, the Reformation, and the flourishing of national literature-strengthened with the reign of James I, when the possibility of a unified Britain appeared. The displacement of characters in Shakespeare's King Lear, whose first performance took place at the court of King James I, and the relevance of Dover, the place where the French invaders disembark, relate to the question of the definition of boundaries and the formation of a national identity in Jacobean England. In Peter Brook's 1970 filmic adaptation of the play, the construction of this identity is metaphorized in the way the film reproduces the barbaric world of Lear in the mise-en-scène- practically bare sets, no music, rough cloth costumes, and wintry landscapes-and relates it to modern-day England in the art-house style of the film and its emulation of a sophisticated form of drama. Thus, the violent deeds of Lear's reign, enhanced in the film, could, due to the characteristic style of art-films of the seventies, address the plights of a nation which can no longer rely on its status as the ruler of the world.

Keywords: King Lear; Peter Brook; film adaptation. 


\section{Shakespeare's King Lear and its relation to the history of England}

When reading the playtext or seeing a performance of King Lear three elements immediately call one's attention: the fact that there is a constant dislocation from place to place-people always seem to be going somewhere; the fact that locations are not clearly specified; and the fact that the only place that is recurrently referred to is Dover. The most amazing thing, however, is that this place, the only one that is so eloquently described-by Edgar in the Dover Cliff scene-is not really "seen". It is only imagined-by the characters of the play and by the audience.

It is from these elements that I want to begin examining the play, the displacements from the restricted space of Lear's castle to the openness of the fields and of the final scenes at Dover. Mathilda Hills points out that "the importance of motion as journey is suggested in part by a total of forty-two occurrences of four related nouns: 'way', 'course', 'journey', and 'pilgrimage.' (...) King Lear never appears in the same location twice" (2). And the importance of Dover can be confirmed by the fact that it is mentioned eleven times in the play. Up to the point when all the characters arrive at Dover-with the exception of the Fool that disappears in Act 3, Scene 6-there is a continuous change of places that, nevertheless, are never clearly delineated.

In relation to geographical space it is possible to distinguish two main locations for the events of the play: the castles and the plains. In a more refined division, it is possible to say that Lear first finds himself in Court and in the houses of his daughters, then moves to the fields where the storm takes place, and is finally found in the plains of Dover beach. But throughout the play there are people on the move. When Regan receives Goneril's letter telling her that their father has left and is heading for her (Regan's) castle, she decides not to be there when he arrives and goes to Gloucester's; Lear sends Kent as a messenger to Gloucester's castle; Goneril and Edmund go to Dover together to meet Albany; messengers carrying letters travel in different directions. In 
short, there is a constant displacement, which in a theatrical performance means actors going on and off the stage.

Amidst all this activity there is a place that stands out, Dover Cliff, for the following reasons: it exists only in Edgar's account; it is given emphasis by a very detailed description; it is a place that evokes the disembarking of the French invaders. Dover is the place where the final confrontation will occur, where Edgar and Edmund will have their showdown, where Lear and Cordelia will meet and die, where Goneril and Regan will lose their lives, where Edgar will accept the mission of ruling the country. Dover $\mathrm{Cliff}$, although not mentioned in the last act of the play, for the action takes place near the sea, is always present. When the French arrive in England, Dover Cliff is probably the first thing that they see.

Most of the crucial events that occur near the end of the play take place in the surroundings of Dover. However, the place is much more vividly evoked in the Dover Cliff scene (4.6), which, in my view, is closely related to those events. This scene deserves, thus, a more detailed investigation. One thing that is surprising in this scene is the amount of words that suggest menace, that suggest that something frightening is lurking somewhere. In the very opening lines, Edgar refers to the ground as "horrible steep" (4.6.4) - the way up to whatever is awaiting them is a difficult one. And then they arrive at the 'top', where Edgar describes what he 'sees' and his description is so feverish that it sometimes brings to mind the nightmarish atmosphere of a Bosch painting-" How fearful/And dizzy 'tis to cast one's eyes so low!" (4.6.15-17). Things seem out of proportion - "The crows and choughs that wing the midway air/Show scarce so gross as beetles" (4.6.18-19). There is a reference to the gathering of samphire as "dreadful trade" (4.6.20). The comparisons made - a man who does not seem bigger than his head, fishermen that walk on the beach and look like mice - evoke disembodied heads and people turned into animals. The view is so frightening that Edgar does not want to look any more, "Lest my brain turn and the deficient sight/ Topple down headlong" (4.6.28-29). 
Dover, at the end of the play, is the place where the feared French invaders will land. If they win the battle against Goneril, Regan, Cornwall and Edmund, they may wish to exercise control over the land; if they lose, power will be in the hands of the evil characters. These are the dreadful alternatives, the nightmarish perspective that Edgar might have foreseen on the fictitious Dover Cliff; they are the abyss, the horror. The fantastic space he creates in his imagination can be equated to the no less nightmarish landscape at the end of the play, with all those deaths and violent deeds. The Dover Cliff scene, then, would metaphorically stand for those feared events. But there is more to it.

Lear is an authoritarian monarch, used to being obeyed without any questioning, as the "love test" scene can clearly show. It is around him that the imagined ancient British community is constructed and in this kind of community, as Donald and Hall point out, reigns dissolve into one another in a way that borders are not clearly defined (Donald 94). The imprecision of places and limits in the old order of things Lear talks of "a third more opulent" (1.1.95) when referring to one of the parts of his kingdom-and the subsequent civil war and defeat of the French - which result in a restoration of order and a restoration of the divided nation - bear a relationship to the actual situation in England at the beginning of James I's reign.

During the reign of Queen Elizabeth I, there began in England a strengthening of national consciousness due to the enmity that England had with France, which had been going on for two hundred years, and the Reformation, with the publication of the English translation of the Bible and a consequent flourishing of national literature. King Lear was written between 1603 and 1606 and its first known performance took place on December 26, 1606 at the court of King James I. Shakespeare and his fellow actors were under the protection of the king: their company, the Chamberlain's Men, had become The King's Men. There is a clear reference to James I in Macbeth as some of Banquo's progeny - the eight spectral kings - carry "two-fold balls and treble sceptres" (4.1.121), an allusion to the fact that James I, who was also James VI of Scotland, joined the two countries (England and 
Scotland), which were, however, ruled separately. There is another reference in Henry VIII, when Archbishop Cranmer praises Elizabeth and her successor who "Shall star-like rise, as great in fame as she was, / And so stand fix'd" (5.4.46-47) (Boyce 315).

With James I a British community is born, although it was not before 1707 that Wales became part of the United Kingdom of Britain. Following the effervescent reign of Elizabeth, with its generous helpings of self-confidence and optimism, and the simultaneous flourishing of poetry and drama, there begins an era with a new sort of concern: how to construct a national identity in a community now involving countries that were once independent. The Enlightened Elizabethan subject, full of confidence in his autonomy and feeling he is the center of the world, now has to enlarge his notion of nation.

This is the point where it is possible to make a connection between the internal space of Shakespeare's King Lear, the space where characters seem to be lost, wandering from place to place to finally arrive at Dover, and the external space of Jacobean England, now joined to Scotland by a common ruler. This ruler, James I, according to Thomas Milles's Catalogue of Honor of 1610, as quoted by Colie (191), also had the title of Albany. Here it is possible to make a relationship between this fact and King Lear, for in the quarto version of the play it is Goneril's husband, Albany, who takes office at the end, an action that parallels James I's taking office as the king of England. It is this Scottish king of the House of Stuart, a house that had ruled Scotland since 1371, who reunites Britain.

Wales had been under English control since 1282, when Edward I's army conquered the Welsh. In 1296 he proclaimed himself king of Scotland, but the Scots rebelled continually and gained their independence when they defeated Edward II in the Battle of Bannockburn in 1314. In Henry VIII's reign, England and Wales were finally united. Although the Welsh had many times risen up against the English, they slowly got used to the idea of union with England. In 1536 both countries were joined under one system of government. But it was only after James I that the possibility of a unified Britain appeared. 


\section{Peter Brook's King Lear and its relation to English history and culture}

Meaning, in relation to the question of national identity, can also be constructed in Peter Brook's filmic rendition of King Lear, but due to the transposition of the play to a twentieth-century medium and also due to the period in which this adaptation was made, this meaning is constructed in a different way, as the arguments below will hopefully confirm, although the play maintains a close relationship with its literary source and the theatrical conventions of Shakespeare's time.

The film King Lear is derived from the 1962 Stratford production of the play. In this filmic adaptation Brook works with a process involving elimination, which had already been used in the theatrical production, dispensing with everything that could stand for warmth and comfort. The film is shot in black and white, most of the time in gray shades, in a desolate wintry landscape in Jutland. Characters are dressed in leather, rough cloth and fur, and settings are practically bare. There is no music. In Brook's words: "The basic principle has to be economy. (...) So the process of preparing Lear all the way was elimination-of scenic detail, costume detail, color detail, music detail" (Brook, Shifting 205). The film, however, does not show economy in terms of a self-conscious filmic style.

Brook's film does not identify the exact time in which the action takes place, but it does not follow from that, naturally, that Brook's Lear exists in a vacuum, unrelated to any historical circumstances. Places are not clearly shown, dates are not specified, costumes do not bring to mind a definite period, but the film is nevertheless clearly British. First of all, even though it uses Shakespeare's text in a very free way, making alterations whenever it finds suitable, Brook's work tries to reconstruct, in filmic terms, the staging conditions of Elizabethan drama. Such a reconstruction is achieved with the help of the technology of the film medium - the possibility of cuts, for instance, that enables the creation of a convincing Dover Cliff scene-and also with the theoretical underpinning of Grotowski's conception of the poor theater. Moreover, the film does not recoil from procedures that are mainly used in the theater, 
like long monologues, and actors facing the camera as they utter their lines. Adapting from the theater, even from his own theatrical productions, is not a new procedure for Brook. In 1989 he adapted for the cinema his nine-hour 1985 production of The Mahabharata. The filmic version of Marat Sade (1967) was produced by the Royal Shakespeare Company and is deeply indebted to the stage - it is presented as Brook's motion picture version of the original stage production The Persecution and Assassination of Jean-Paul Marat as Performed by the Inmates of the Asylum of Charenton under the Direction of the Marquis de Sade (VHS ISP 8006). In relation to this film, Brook said:

(...) with three, sometimes four cameras working non-stop and burning up yards of celluloid, we covered the production like a boxing match. The cameras advanced and retreated, twisted and whirled, trying to behave like what goes on in a spectator's head and simulate his experience; attempting to follow the contradictory flashes of thought and stomach blows with which Peter Weiss had filled his madhouse. (Brook, Shifting 189)

Brook's words clearly show how he tried to reproduce a theatrical experience in Marat Sade. There is even an audience that is intermittently shown attending the play. When Charlotte Corday pays a visit to Marat, she knocks on an invisible door, while an actor taps on the floor with a cane in order to make the corresponding sound. This approach goes against the idea that a film ought to show a real door of a real house, with the sound of the knocking synchronized with the action of knocking. Like Marat Sade, but to a lesser degree-for there are outdoor scenes and naturalistic settings-King Lear is very close to a theatrical experience. Thus, to a certain extent, as Kent and Cordelia have been banished by Lear, cinema has been banished from Brook's Learin order that the theater could be celebrated. However limited this view may be -for there are moments of artful mise-en-scène in the film, which relate it to the sophisticated European cinematic culture of the sixties 
and seventies-the fact is that the film's mise-en-scène enhances the theatrical text. For even in those few moments referred to above, the stylistic devices, which are very self-conscious, seem to serve the theatrical text, that is, they seem to be there to highlight it.

\subsection{Brook's King Lear and the art-house film style}

Besides the aspect discussed above, that Brook's filmic adaptation is closely related to a theatrical experience, it is also very rich in expressive devices that were common in art-house films of the sixties and seventies. Here are some instances: 1 . As banished Kent starts to disguise himself in order to serve Lear, he engages in a monologue. After every profession of loyalty to Lear (in the playtext these lines are an answer to a question asked by Lear), the camera zooms in on Kent's face and there is a brief fade-out, so that the whole monologue involves a sequence of zoom-ins/fade-outs. 2. There are card captions inserted at certain moments of the narrative. Besides filling in narrational gaps, they contribute to the feeling of distancing experienced by the spectator by making him/her aware that he/she is viewing a film. 3. At Goneril's castle Lear insistently asks where his Fool is. When they finally meet, the camera pans very rapidly to the left and to the right, from Lear's face to the Fool's. 4. The open form is the norm-people go into and out of the frame or are placed at the borders-whereas in the classical film the closed form is more frequent. 5. When Edgar says "I am nothing", he is completely out of focus. 6 . In the storm sequence there is a very fast editing of Lear's and the Fool's close-ups to suggest the Fool's wisdom and Lear's foolishness by almost superimposing both faces. In the same storm sequence there is a wide variety of resources: out-offocus photography, jump cuts, and, most important of all, the violation of the $180^{\circ}$ rule, which allows the camera to show Lear in profile, first on the right side of the frame, then on the left side. 7. The film also presents an impossible POV shot as Lear approaches Edgar from behind: Edgar faces the camera, a shadow projected on the sand approaches, there is a cut to an extreme overexposed close-up of Lear's face, then Edgar turns round and sees him. 8. The final battle is only heard, while the camera 
shows parts of Gloucester's face sometimes out of focus, sometimes sharply focused-a resource that translates the presentation of Gloucester sitting alone on the stage as the battle takes place offstage in the Stratford production. 9. After Edmund and Edgar fight at the end of the film and Edgar wounds Edmund, there are symmetrical closeups of the two brothers-Edmund's upside down-a scene described elsewhere, with a different purpose. 10. Cordelia appears by Lear's side after she has been hanged. That can be Lear's hallucination, but it is devised in a strange way, for she is some steps behind him, and he does not seem to be aware of her presence.

As the examples above show, there is a relatively large collection of cinematic resources in the film and they are ostensibly displayed, which evinces the fact that Brook shows a concern with cinema, mainly art cinema: his film exploits a wide variety of cinematic devices. It often does that, however, in order to stress Brook's theatrical conceptions. There is also the inescapable association of a nihilistic view of the world, together with the techniques characteristic of art films of the 1960s and 1970s - blurred images, jump cuts, hand-held camera - with an era of unrest, of socio-political changes, of sexual and moral revolutions. In these times, an anarchist type of theater-in which the director is the star, not the actor or the author-flourishes and becomes a source of theatrical renovation. It is the time of Peter Weiss and his groundbreaking play Marat Sade and Peter Brook, who made a filmic adaptation of Marat Sade, is part of that theatrical environment. It is that innovative type of theater that the film's artful mise-en-scène celebrates.

Thus, it is possible to consider the whole set of filmic devices described above as a metaphor for the reverence that the film shows for the theatrical experience. Besides, the jump cuts, the out-of-focus or overexposed photography, the impossible POV shots, the open form and other devices employed in the film can be further metaphorized, for they evoke aspects of British life of the sixties and seventies, which will be discussed in the next section. 
2.2. Brook's Lear and British cultural aspects of the sixties and seventies

The unity of the United Kingdom was due mainly to a shared Protestantism and to a series of victories against France, from which emerged a vast empire encompassing India, Canada, and the West Indies. Britain, in the nineteenth century, was further united by the railway system, which made the Empire supranational, "with the English, Irish, Scots, and Welsh alike serving in the British Imperial Army, Ireland providing colonial viceroys and governors, and the Empire being seen as distinctively British rather than specifically English" (Richards 8). Evangelical Protestants in the nineteenth century managed to ban slave trade and public executions, gambling and drinking, and promoted respectability, sobriety, and restraint. At the same time courtesy, chivalry, and bravery were hailed, as we can see in the very popular works of Walter Scott. "The idea of the gentleman was an integrative image for the ruling elites of Great Britain, (...) transcending the boundaries between England, Scotland and Wales" (12). Richards also points out the ideology that the British Empire was run not for their own benefit but for the benefit of the ruled, which had as a consequence the sense of British superiority. He says: "The idea of English superiority to foreigners is inculcated in its citizens from an early age and is embodied in the juvenile literature to which the English young have been exposed since the arrival of mass literacy in the nineteenth century" (12).

But in the late 1960s, when the British Empire had already lost most of its colonies, such as Ireland, India, Pakistan, Myanmar, Sri Lanka, Ghana, Nigeria, Cyprus, Sierra Leone, Tanzania, Jamaica, Trinidad \& Tobago, Uganda, Kenya, Malaysia, Malawi, Malta, Zambia, The Gambia, and Singapore ${ }^{1}$, there had already begun a great change in the British social, economical, and political situation: "The background to this cultural revolution was the affluence, full employment and materialism of the 1950s and 1960s which released people from the immediate disciplines of survival and turned their attention to their 'expressive' needs - self-discovery, self-assertion, sensation" (Richards 
18). And the old Victorian values of respectability and puritanism were rejected and replaced by more liberal attitudes: the abolishment of capital punishment, the legalization of homosexuality and abortion, the greater tolerance to drinking and gambling. Parallel to these welcomed changes there were unwanted ones, according to Richards: "During the 1960s crimes of violence doubled, convictions for drunkenness rose by three-fifths, there was a tenfold increase in drug addiction. Vandalism spiralled. Football hooliganism, previously virtually unknown, blighted the national game" (19). Likewise, Protestantism declined in such a way, says Richards, that Britain became one of the most secularized countries in the world. He also affirms that suicide rates have increased in 70 per cent from the seventies on and that one in three young men in Britain has a criminal record (24). To complete the bleak picture, from the seventies on there have also occurred occasional bursts of racism against colored immigrants.

It was in this scenario that emerged the British New Wave Cinema which, influenced by the literary and theatrical movement of the "angry young men", focused on working class themes in northern locations and black-and-white photography. Look Back in Anger (1959), Room at the Top (1959), A Taste of Honey (1961), Saturday Night and Sunday Morning (1960), The Loneliness of the Long Distance Runner (1962), A Kind of Loving (1962), and This Sporting Life (1963) belong to this period. Peter Brook began to make films in 1943, but most of his filmic production belongs to the period discussed above. Moderato Cantabile was released in 1960, Lord of the Flies in 1963, Marat/Sade in 1966, Tell Me Lies in 1967 and King Lear in 1970. These films are unrelated to the New Wave movement, for they do not deal with young working class heroes at odds with unemployment in provincial towns; however, the crude black-and-white photography of Lord of the Flies and its dark view on British society are not completely alien to the mood of disenchantment of those films. Presented as a parable describing the disintegration of a British society of boys stranded on a deserted island, who strive to organize themselves in a civilized way_- After all, we're 
not savages; we're English", says one of the boys - Lord of the Flies culminates in anarchy and slaughter.

In the same year that Lord of the Flies was shot, there was the production of Tony Richardson's Tom Jones, which set the tone for the 'swinging London' films to come in the remaining years of the decade. With its irreverent and zestful style - speeded-up action, captions, asides to the camera, the film prepared the way for Smashing Times (1967), The Amorous Adventures of Moll Flanders (1965), Play it Cool (1962), The Knack (1965), Help (1965) and Modesty Blaise (1966). But Peter Brook's King Lear, produced in 1971, did remain faithful to the spirit of Lord of the Flies and of Marat Sade, released in 1966. Although Brook's films cannot fit in the British New Wave Cinema, they suffered not only its influence but also that of the European filmic world of the time. Filmmakers were testing the limits of the cinematic narration in many countries: Antonioni made L'Avventura and Pasolini made Teorema in Italy; Godard directed À Bout de Souffle and Alain Resnais L'Année Dernière à Marienbad in France, for example. To this group belongs Brook's Moderato Cantabile, which tells the story of an industrialist's wife who has a love affair with a worker in her husband's factory. In Lord of the Flies and Marat/Sade, films which do not fit the British New Wave Cinema-as has already been mentioned - the world that Brook depicts is a world of madness, chaos, and hopelessness, which is not unrelated to those key works of European cinema referred to above.

\subsection{The barbaric and the civilized worlds of King Lear}

In order to deal with the ways in which this brutal and absurd world is treated in Brook's adaptation of King Lear, it is necessary to take into consideration that there are two worlds in King Lear-one related to ancient history, to a semi-nomadic society, represented by Lear's plot; and another related to a civilized world, recognized by a Jacobean society for its familiarity, represented by Gloucester's plot. These two worlds would conflict and as a result there would be the disruption of an unjust tyrannical rule and a consequent reordering of the political situation due to Edgar's ascension to the throne. In spite of 
the conflict, these two worlds would co-exist in a relation of codependence-an awareness of an ancestral England would all the time pervade the contemporary event of the reunion of the kingdom by Edgar. A feeling of national consciousness would thus be born, with the performative- the elements of Elizabethan contemporary culture -and the pedagogic - the tradition and past history-making up a unity. Thus, Lear's barbaric world, the more remote world, would not be the cause of Gloucester's. Both worlds would intermingle.

It is the barbaric world that is highlighted in Peter Brook's King Lear. In the first scenes of the film Lear is dressed in a kind of fur overcoat that provides him with a huge furry hump, which makes him look like a wild beast; when he says farewell to Goneril, calling her "a disease that's in my flesh", she is seen in profile, and the furry collar of her coat hides part of her face and makes her look like a beast too; deaths are sudden and violent, as we have seen above; good and bad characters are not clearly distinguished; the landscape is barren and the castles look plain and cold; the furniture is rough and reduced to its essential. This barbaric and ruthless world can be related, metaphorically and hyperbolically, to some dark aspects of Great Britain at the time the film was shot: the increase of criminality and of suicide rates, and the growing intolerance with immigrants, for example. Due to Brook's reading of the play, the civilized world of King Lear is not apparent in the film. Neither is the civilized world of his contemporary Britain, which was not apparent in Lord of the Flies either.

It is necessary to note, however, that this civilized world is not apparent in the content of the film, but can be clearly detected elsewhere, for civilization, more precisely Western civilization, is present in those elements already mentioned-the film's theatrical conventions and cinematic resources. Seen from this perspective, King Lear is a very sophisticated film: it tries to recreate the conditions of one of the most renowned eras of British drama and to use a sort of filmic discourse that inserts it in the category of art film. Thus, the dichotomy performative/ pedagogic does not work in the film in the same way as in the playtext. We do not have the contemporary elements that a Renaissance audience 
had in the Gloucester's plot, with its views on justice, customs, and science. These views are absorbed by the ancient elements of the play. Everything in the film is barbaric, ancestral Englishness, that is, everything in the film diegesis belongs to the pedagogic-a concept developed by Bhabha (cf. Chapter IV, section 2)-to the tradition of the people, to history. But at the same time these barbaric elements of the film belong to the performative- "the scraps, patches, and rags of daily life that must be repeatedly turned into the signs of a national culture" (Bhabha 297)-in that they metaphorize the film's contemporary culture.

On top of that, the performative would also be represented by the things that relate the film to modern day Britain: its reverence to a respected form of theatrical presentation - the Elizabethan dramaand to a highly regarded filmic approach: the art film of the sixties and seventies. National consciousness would then result from the combination of the awareness of a tradition that goes back to the barbaric times of King Lear-which is somehow present up to this day-and the celebration of a theatrical form in which the British excel, together with a type of narrative characteristic of the European art cinema. Thus the whole film metaphorically stands for the British awareness of the relevance of its culture and of European thinking. The bleak, nihilistic view of the film is related to theatrical experiments of the sixties-the Theater of the Absurd, the Theater of Cruelty, the Poor Theater-and to the philosophical existentialist ideas of postwar Europe.

Brook's King Lear, with its stylization and imprecision of locale, seems to have avoided any political statement in terms of a national identity. But it has not. That brings to mind the question insistently asked in the playtext and in the film: Wherefore to Dover? A possible answer would be to reaffirm national pride and cultural values in the staging of a revered work in a way that reinforces the most glorious period of English drama. The Dover Cliff scene, the scene analyzed in section 1 of this article, is staged with very few elements in Brook's film -the setting is almost non-existent, the dialogue directs the action, close-ups predominate over long shots and medium shots, there is no 
color and no music to add information to the scene. And the scene simultaneously evokes the bareness of Brook's, and Shakespeare's, stage and depends on cinematic features—cuts, offscreen space-and a highly self-conscious style to maintain the ambiguity of a space that exists and does not exist at the same time. The scene is a tour-de-force. The whole film, incidentally, is a tour-de-force. It is proud of its source, it is proud of its style, it is even proud of its mood of despair. In spite of this mood, order is restored at the end, when Edgar takes power. Nevertheless, the last image of the film can be read as expressing nothingness, like the "know" ("no"?) that is the first word heard in the film: the dying Lear slowly falls out of the frame, repeated times, and we are left with a totally blank screen for a while. And then the nonexistent image fades to black. But it can be read differently. It is this blank screen - the ultimate empty space-that has to be filled with the answer to the question: "Wherefore to Dover?"

Issues of Britishness thus arise as we consider the unsettling position of a nation that, having ceased to be a dominating empire, having lost the traditional parameters of opposition-to Catholicism and to the French-, is concerned with the process of becoming European, of redefining its identity. King Lear was made in the seventies and, as Hall points out, "it is generally agreed that, since the 1970s, both the scope and pace of global integration have greatly increased, accelerating the flows and linkages between nations" (299). In the British panorama, thus, there would be the tension between two forces-the particularistic identities of the countries that make it up and that would rather walk towards autonomy, and the necessary integration with other communities. As a result, a feeling of instability would be created, a feeling that the blank shot at the ending of King Lear could metaphorize. It is in this symbolic space that the national identity of the British subject can be located, for surely the decentered subject that can be entertained with the combination of angst, nihilism, pride in traditional and cultural values - the Renaissance drama, the European art cinema-differs from the Enlightened Jacobean subject 
that could be entertained with the controlled, unified space of Shakespearean drama.

\section{Note}

1. Mathilda Hills Shakespeare's King Lear Hall, Politics and Ideology Brook, Shifting Richards Bhabha (cf. Chapter IV, section 2).

\section{References}

Bhabha, Homi K. (ed.). Nation and Narration. London: Routledge, 1990.

Boyce, Charles. The Wordsworth Dictionary of Shakespeare. Ware: Wordsworth Reference, 1996.

Brook, Peter. The Empty Space. New York: Touchstone, 1996.

. The Open Door. New York: Theatre Communications Group, 1995.

. The Shifting Point: theatre, film, opera, 1946-1987. New York: Theatre Communications Group, 1987.

Butler, Guy. "King Lear and Ancient Britain". Theoria: a Journal of Studies in the Arts, Humanities and Social Sciences, Pietermaritzburg 65 (Oct 1985): 27- 33.

Clark, S. H. "'Ancestral Englishness' in King Lear." Shakespeare Studies (Sh Stud), Japan 31 (1996): 35- 63.

Colie, Rosalie L. "Reason and Need: King Lear and the 'crisis' of the Aristocracy." In: Colie, Rosalie L., and F. T. Flahiff (eds.). Some Facets of King Lear: Essays in Prismatic Criticism. London: Heinemann, 1974. 185- 219.

Colley, Linda. "Britishness and Otherness: an argument". In: O'Dea, Michael, and Kevin Whelan (eds.). Nations and nationalisms: France, Britain, Ireland and the eighteenth-century context. Oxford: Voltaire Foundation, 1995. 61-77.

Donald, J., and S. Hall (eds.). Politics and Ideology. Milton Keynes: Open University Press, 1986. 
Gellner, Ernest. Nations and Nationalisms. New York: Cornell University Press, 1983.

Grotowski, Jerzy. Towards a Poor Theatre. London: Methuen, 1975.

Hills, Mathilda M. Time, Space, and Structure in King Lear. Salzburg: Institüt für Englische Sprache und Literatur, Universität Salzburg, 1976.

Hobsbawn, Eric J. Nations and Nationalism since 1780: Programme, Myth, Reality. Cambridge: CUP, 1990.

Hunt, Albert, and Geoffrey Reeves. Peter Brook. Cambridge: Cambridge University Press, 1995.

Mowat, Barbara A., and Paul Werstine (eds.). The Tragedy of King Lear by William Shakespeare. The New Folger Library Shakespeare. New York: Washington Square Press, 1993.

Richards, Jeffrey. Films and British National Identities. Manchester and New York: Manchester University Press, 1997. 